\title{
Urban Network Analysis and Pathology in Central Texture of Mashhad Metropolis from a Passive Defense Point of View, Case Study of Mashhad Municipality, Mashhad, Iran
}

\author{
Reza Nazeran $^{1}$, Neda Rafati Sokhango ${ }^{2}$, Aida Nasiri Kalat ${ }^{1}$, Kaveh Ostad-Ali-Askari ${ }^{3 *}$, \\ Saeid Eslamian ${ }^{4}$, Vijay P. Singh ${ }^{5}$, Nicolas R. Dalezios ${ }^{6}$ \\ ${ }^{I}$ Department of Civil Engineering, Sadjad University of Technology, Mashhad, Iran. \\ ${ }^{2}$ Department of Architectural Engineering, Sadjad University of Technology, Mashhad, Iran \\ ${ }^{3 *}$ Department of Civil Engineering, Isfahan (Khorasgan) Branch, Islamic Azad University, Isfahan, Iran. \\ ${ }^{4}$ Department of Water Engineering, Isfahan University of Technology, Isfahan, Iran. \\ ${ }^{5}$ Department of Biological and Agricultural Engineering \& Zachry Department of Civil Engineering, Texas A \\ and M University, 321 Scoates Hall, 2117 TAMU, College Station, Texas 77843-2117, U.S.A. \\ ${ }^{6}$ Laboratory of Hydrology, Department of Civil Engineering, University of Thessaly, Volos, Greece \& \\ Department of Natural Resources Development and Agricultural Engineering, Agricultural University of \\ Athens, Athens, Greece.
}

*Corresponding Author: Dr. Kaveh Ostad-Ali-Askari, Department of Civil Engineering, Isfahan (Khorasgan) Branch, Islamic Azad University, Isfahan, Iran.Emails: Koa.askari@khuisf.ac.ir, Kaveh.oaa2000@gmail.com

\begin{abstract}
City is a compact human habitat which due to the presence of human beings requires safety and security in all the physical, social, economic, cultural, and managerial dimensions. Any action that secures the human society, its natural and artificial environment, is considered passive defense if the approach is protection-based and the action, non-military. The issue of defensive urbanization and the role of passive defense in the life of the cities have been fundamental in urbanization studies and urban planning since ancient times. Attention to this issue in the Holy City of MASHHAD, as a religious metropolis and the spiritual capital of the nation with over 30 million pilgrims per year is very important.

The urban network could be considered an important vulnerable factor in urban areas which is in close relationship with securing escape space and safe places during air and land attacks of enemies and increasing the efficiency of rescue operations after crisis. The accessibility levels of a texture, in terms of both sheltering at the time of crisis, and during rescue, would have an effective role in increased/decreased number of casualties. Therefore, by designing an efficient communication network, the casualties could be reduced significantly.

This is a descriptive-analytic study; and data have been collected through library-survey methods. Considering the existing and available data, the passageways network of the study area (Zone 1, District 8 of Mashhad Municipality) has been examined based on two indicators, namely, the passageways to total ratio in terms of passageway width, and the pregnability level of the texture within the study area; and the vulnerability caused by the urban network inside that texture has been addressed. Examinations indicate the presence of inefficient urban network and high vulnerability levels of the study area in terms of passive defense.
\end{abstract}

Keywords: Passive Defense, Texture around Razavi Shrine of Mashhad, Urban network, Vulnerability

\section{INTRODUCTION}

In today's world, the issue of passive defense has drawn a lot of attention as an important topic and the discussion related to security and defense of a nation and its cities has become necessary. Therefore, when planning for defensive security, not only protecting human lives should be taken into consideration, but also, retaining a city's structure and all of its achievements including economic, social, and ... would be of interest.

Mashhad, as an Iranian metropolis and the spiritual capital of the nation, while considered a center of population, requires special attention to the issue of passive defense. The aim of this study is to 
examine the texture surrounding Razavi Shrine within the study area in terms of urban network vulnerability level, accessibility levels during crisis, and the area's passive defense potentials.

Passive defense refers to a collection of non-military activities which would increase in inhibition, decrease vulnerability, elevate national resistance, enable the continuation of vital activities, and facilitate crisis management against hostile threats and military actions [1].

One purpose of passive defense is to provide for essential and vital human needs during the enemy's destructive activities and attacks through appropriate planning. Therefore, the best ways to apply the principles of passive defense are culture-building and training the general public. Additionally, shielding population centers would ensure the viability and resistance of a city because reconstruction would be impossible during a conflict. Therefore, it is vital that passive defense measures be taken before a crisis begins.

This study tries to identify the urban texture surrounding Razavi Shrine inside the study area (Zone 1, District 8 of Mashhad Municipality) in terms of access roads and passageways network; and explore its potentials from a passive defense viewpoint.

\section{THEORETICAL FOUNDATION}

\subsection{Significance of Passive Defense in Urban Viability}

There are two kinds of defense: active and passive. Active defense is achieved using military devices and equipment by military personnel with the objective of mutually attacking the enemy; while passive (civil) defense does not require military equipment and is mainly based on architecture and design of spaces, as well as structures' strength and sustainability in safeguarding human lives and urban viability. Saving human lives is the main purpose of passive defense which would be achieved by building structures that would withstand offensive action, explosions, and that would provide safe havens for hiding and use as shelter. Also, presence of a sufficient number of service and rescue centers with sufficient safety and structural resistance to ensure fast and easy service would complement that objective. Hideouts should be located such to enable usage and access in the shortest spans of time.

Time is of paramount importance under hostile attack conditions and crisis circumstances. Therefore, appropriate and correct planning of urban spaces and building strong structures with a regard for passive defense measures would lead to reduced vulnerability, urban viability, and unbroken chain of vital activities during crisis. An objective which would be further achieved by the presence of efficient passageways network created in accordance to modern urbanization principles which is based on passive defense itself.

\subsection{Role of Passive Defense in Open Spaces}

Urban open spaces are the most importance spaces in passive defense because they are the least defended areas during hostile attacks; and after the crisis, too, they have the best conditions for rescue operations. Therefore, by designing such spaces properly and compatible with passive defense, vulnerability could be reduced.

Inattention to urban design and the principles of passive defense because of speedy construction and ever-increasing urban population has allowed buildings and open spaces (inter-building spaces such as streets, parks, and alike) to be formed without a consideration for urbanization principles and without interrelations [3].

\section{STUdy AREA}

The City of Mashhad is on the north-east of Iran, to the north of Khorassan-e- Razavi Province. It covers an area of $288 \mathrm{Sq} \mathrm{Km}$ located between Binalood and Hezarmasjed mountain ranges. Its height from sea level is $985 \mathrm{~m}$. The plain of Mashhad is located between $58^{\circ} 20^{\prime}-60^{\circ} 8^{\prime}$ longitudes and $35^{\circ} 40^{\prime}-36^{\circ} 3^{\prime}$ latitudes northern on the north-east of Iran.

On the tectonics and faults of the area it should be said: thrust faults and overthrust plate form the majority of tectonic constructs of Mashhad area. Almost all of the thrust faults have a northeastsouthwest movement; and their direction on the edge is from north and northwest to south and southeast. Folds are observed in almost all types of rocks. Wrinkles in the south of Mashhad are mainly isoclinals and overturned; and their existence has been directly related to the activity of thrust 
faults and the movement of over thrust plates. They are all overturned to the direction of south and southwest; and their axial slope is toward north and northeast. Seams, too, are among the prevalent constructs present in all of the sedimentary, igneous, and metamorphic rocks of the area which are the product of breaking behavior against the forces applied to them.

Main faults of the region are:

Jaffari fault, an overthrust one, to the northeast of Tabadkan.

Ahmadabad fault, an overthrust one with many ruptures, has a general northwest-southeast direction.

Kheirabad fault, a thrust one, has a near northwest-southeast direction.

Mansar fault is a secondary extension of the latter.

Shandiz-sangbast fault, the major fault across Mashhad region, appears as a separation line of northern skirt of Binalood and plain of Mashhad; and in fact, is the jointure of Tooran and Iran plates. This fault is of thrust typology with a northwest-southeast direction.

The study area consists of Zone 1, District 8 of Mashhad Municipality which is located on the texture surrounding Razavi Shrine and is bordered by Khosravino St. to the north; by Emam Reza St. to the east; Malek-al-Shoaraye Bahar St. to the south; and Daneshgah (University) St. to the west; with an area of 3,223,967 Sq m. compact texture with very small parcels of land have occupied a considerable area in this zone. This area has an old an worn texture which over time, and by expansion of the city, and due to the existence of Razavi Shrine, attracting a great number of pilgrims from various parts of the nation and the world, for more suitable servicing and renovation and reconstruction of existing worn texture, involves a number of problems such as miniature and worn-out residential texture, environmental pollution, high population density, shortage of services and utilities, and inappropriate distribution thereof.

\section{METHODOLOGY}

During the research conducted on the urban network within the study area, the percentage of passageways network relative to the total in terms of passage width has been presented into a table:

Table1. The percentage of passageways network relative to the total in terms of passage width inside the study area

\begin{tabular}{|c|c|}
\hline Passageway width & Single passageway to overall ratio (\%) \\
\hline$>2 \mathrm{~m}$ & 6.94 \\
\hline $2-4 \mathrm{~m}$ & 21.65 \\
\hline $4-6 \mathrm{~m}$ & 18.66 \\
\hline $6-8 \mathrm{~m}$ & 14.56 \\
\hline $8-10 \mathrm{~m}$ & 10.55 \\
\hline $10-12 \mathrm{~m}$ & 5.01 \\
\hline $12-14 \mathrm{~m}$ & 0.59 \\
\hline $14-16 \mathrm{~m}$ & 1.53 \\
\hline $16-18 \mathrm{~m}$ & 3.76 \\
\hline $18-20 \mathrm{~m}$ & 2.47 \\
\hline $20-22 \mathrm{~m}$ & 3.13 \\
\hline $22-24 \mathrm{~m}$ & 4.01 \\
\hline $24-26 \mathrm{~m}$ & 4.01 \\
\hline $26-28 \mathrm{~m}$ & 3.12 \\
\hline $28-30 \mathrm{~m}$ & 0 \\
\hline $30+\mathrm{m}$ & 0 \\
\hline
\end{tabular}

Considering the table above which indicates the width relation of single passageways to the overall in percentiles inside the study area, it is observed that passages of a width of $>2 \mathrm{~m}$ to $12 \mathrm{~m}$ account for 5$21.6 \%$; and those of $12-28 \mathrm{~m}$, between .06 and $4 \%$ of the overall passageways inside the study area. Moreover, given the data in the table, passages $28+\mathrm{m}$ wide do not have any share inside this area.

\subsection{Relationship between Urban Network and Service and Rescue Centers}

Hospitals are among the most important and most vital centers which, under the enemy attack conditions and in critical circumstances, should always be sustainable and ready to serve. In terms of degree of importance, they are considered highly important structures. Therefore, hospitals should 
have a sustainable structure, resistant to explosions and other damages. Furthermore, selecting a suitable location for building a hospital structure is highly important because it would enable easy and speedy servicing in critical circumstances. Another highly important issue which complements the sustainability of servicing of such facilities even under crisis conditions, is the existence of powerful and suitable passageways network.

Existence of a network of passageways which are developed in line with passive defense principles could enable easy, fast rescue and transfer of the wounded. Thus, if the passages have sufficient space for the movement of rescue vehicles, even in the conditions after the collapse and destruction of buildings, rescue would be performed easily.

Fire stations, too, should exist in sufficient numbers inside each block/neighborhood depending on the block size; and also, sufficient and suitable space should exist on the passageways to enable their servicing at the times of crisis. That is, necessary clearance should be provided for the correct and appropriate use of fire extinguishing equipment during crisis, which would not be possible unless there is a network of passageways which is proportional to today's needs.

\section{CONCLUSiON}

\subsection{Status of Passive Defense in Mashhad's Urban Network Inside the Study Area}

Inside the study area, most streets and alleys have a small width while the density of development in this area is very high and the width of passageways is not proportional to the existing density. This would create abundant problems during a possible war and under assault conditions, such as buildings collapsing or streets blocking after a bomb or rocket hits them. Especially there is the issue of complete blockade of alleys which are very disproportional in terms of width and development density. This would create huge problems for rescue, fire extinguishing and transfer of the wounded eventually; or even lead to the paralyzation of communication network.

As seen in the table, a large portion of the area has been assigned to passages of 2-10 m width. Such a width would not be sufficient for the density and the traffic in this area. At the same time, very significant portions have been allocated to passages over $12 \mathrm{~m}$ wide.

Open spaces should be designed to provide easy and fast access to vital elements such as shelter, health centers, fire departments, hideouts, and alike during crises [4]. As such, the study area would not meet this requirement under war conditions.

During air raids, adjacent building masses would draw more hostile attention because of their high density, would be easily targeted and hit by rockets; and their collapsing would block the passageways due to their small width. However, if existing buildings be arrayed in a geometrically appropriate manner with attention to the principles of passive defense, and have appropriate dispersion, and also, if the width of passageways have a specific proportionality relative to the density, in addition to decreased possibility of damaging the building texture, the potential for the open space to remain untouched will increase.

The study area has a fine-grained dimension and a high concentration of building masses which has been a function of high population in the area. Moreover, disregard for modern urbanization principles and rules has increased its vulnerability to air raids.

\subsection{Relationship between Urban Network and Service and Rescue Facilities Inside the Study} Area

The number of hospitals inside the study area is suitable for servicing under war crisis conditions. Seven hospitals cover the area, namely, Emam Reza Hospital, Ghaem Hospital, Bent-al-Hoda Hospital, Shahinfar Hospital, Arya Hospital, Musa-bin-Jaffar Hospital, Sina Hospital, in addition to four Red Crescent Centers. Unfortunately, the inefficient passageways network would lead to the paralyzation of rescue operations during a conflict at many a point inside the study area. In passages 2-4 $\mathrm{m}$ wide, accounting for the highest percentiles of passages inside this area (21.65\%), such services would be performed slowly and very arduously; and even sometimes, service and rescue would become impossible due to debris and blocked passages.

Given the foregoing, in current conditions and present great focus of passive defense topics, it is necessary that the principles and rules of passive defense be seriously observed in new urban developments and old urban textures be reconstructed and improved such that all proportions in 
urbanizations, including the proportion between density and type of passageways be observed based on passive defense principles and rules.

The Holy Mashhad, as a religious metropolis, is one of the cities where the observance of passive defense principles seems very necessary. An important area of this religious metropolis is the one surrounding the Holy Razavi Shrine as the main nucleus of the city which has a very dense population. Unfortunately, this area has a weak passageways network in terms of sustaining transport and traffic of vehicles and pedestrians which would create huge losses of lives and properties under the conditions of war and crisis. Issues such as the improvement of worn out and inefficient texture and enhancing the efficiency of urban network and open spaces (landscapes) during a possible crisis, and expanding them along with some measures aimed at designating suitable spaces for use under crisis conditions which have convenient access based on the defense principles are among the issues in the realm of passive defense to be taken into account by urban management of the greater Mashhad. Therefore, converting the passive defense principles into urbanization principles in order to achieve the passive defense objectives is highly crucial.

6. Suggestions

Given the foregoing, effective indicators in achieving a desirable level of passive defense readiness inside the study area are:

- Reducing population convergence in order to decrease density;

- Creating proportionality between open spaces (landscapes) and development compactness;

- Planning toward renovation and improvement of worn out texture in compliance with passive defense requirements;

- Coordinating the urban texture inside the study area with those with newer texture;

- Allocating more space to passageways to facilitate traffic and servicing under critical conditions;

- Providing for a powerful urban network in terms of environmental proportionality with easy, fast access routes from other points.

\section{REFERENCES}

[1] Ostad-Ali-Askari, K., Shayannejad, M. 2015, The Reviews of Einstein's Equation of Logarithmic Distribution Platform and the Process of Changes in the Speed Range of the Karkheh River, Khuzestan province, Iran. International Journal of Development Research, 5(3), 3786-3790.

[2] Ostad-Ali-Askari, K., Shayannejad, M., Ghorbanizadee-Kharazi, H. 2015, Assessment of artificial neural network performance and exponential regression in prediction of effective rainfall, International Journal of Development Research, 5(3),3791-3794.

[3] Shayannejad, M. Akbari, N. and Ostad-Ali-Askari, K. 2015, Determination of the nonlinear Muskingum model coefficients using genetic algorithm and numerical solution of the continuity. Int. J. of Science: Basic and Applied Research, 21(1),1-14.

[4] Ostad-Ali-Askari, K., Shayannejad, M. 2015, The Study of Mixture Design for Foam Bitumen and the Polymeric and Oil Materials Function in Loose Soils Consolidation. Journal of Civil Engineering Research, 5(2), 39-44. DOI: 10.5923/j.jce.20150502.04

[5] Sayedipour, M., Ostad-Ali-Askari, K., Shayannejad, M. 2015, Recovery of Run off of the Sewage Refinery, a Factor for Balancing the Isfahan-Borkhar Plain Water Table in Drought Crisis Situation in Isfahan Province-Iran. American Journal of Environmental Engineering, 5(2): 43-46. DOI: 10.5923/j.ajee.20150502.02

[6] Ostad-Ali-Askari, K., Shayannejad, M. 2015, Developing an Optimal Design Model of Furrow Irrigation Based on the Minimum Cost and Maximum Irrigation Efficiency. International Bulletin of Water Resources \& Development, 3(2), 18-23.

Citation: R. Nazeran et.al. “ Urban Network Analysis and Pathology in Central Texture of Mashhad Metropolis from a Passive Defense Point of View, Case Study of Mashhad Municipality, Mashhad, Iran”, International Journal of Constructive Research in Civil Engineering, 4(1), pp.44-48. DOI: http://dx.doi. org/10.20431/2454-8693.0401005

Copyright: (C) 2018 Dr. Kaveh Ostad-Ali-Askari, This is an open-access article distributed under the terms of the Creative Commons Attribution License, which permits unrestricted use, distribution, and reproduction in any medium, provided the original author and source are credited. 